\title{
A retrospective study to evaluate the efficacy of a new antibiotic adjuvant entity (B-lactam/B-lactamase inhibitor/adjuvant disodium edetate combination) for management of sepsis
}

\author{
Sachin Verma \\ Correspondence: sachinverma.265@rediffmail.com

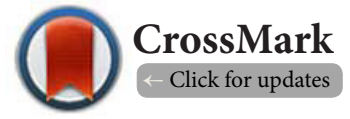

Internal Medicine and Critical Care, IVY Hospital Mohali, Punjab, India.

\begin{abstract}
Aim and objective: The management of patients with sepsis and septic shock requires an integrated approach of accurate diagnosis along with rapid initiation of appropriate antimicrobial therapy. Here we present a retrospective analysis of a new therapy opted and outcome of the patients suffering from gram negative bacterial sepsis.

Materials and methods: A retrospective study was conducted to evaluate efficacy of new antibiotic adjuvant entity (Ceftriaxone+sulbactam+adjuvant disodium edetate) in 45 patients (showing sensitivity to AAE) with gram negative bacterial sepsis, treated at tertiary-care hospital between March 2013 to December 2014. AAE therapy was initiated empirically and continued based on the results of the in-vitro microbiological susceptibility testing and clinical outcome.

Results: Out of 45 patients, 37 (82.22\%) patients were diagnosed with bacterial infections, which are susceptible to AAE, where as the $8(17.18 \%)$ bacteria showed intermediate susceptibility towards AAE. Out of 37 patients treated with AAE, successful clinical response was observed in $25(67.56 \%)$ patients with AAE alone, while in remaining 12 patients clinical cure was achieved with AAE and Colistin combination therapy. 08 patients with bacteria showing intermediate susceptibility towards AAE were successfully cured with AAE and colistin combination therapy.

Conclusion: AAE with its adjuvant and beta lactam/beta lactamase inhibitor combinations has the potential to be considered as a safe and efficient treatment option against gram negative bacterial sepsis. It provided clinical and microbiological cure both in mono and combination therapy used against gram negative bacterial sepsis.
\end{abstract}

Keywords: Ceftriaxone/sulbactam-disodium edetate, gram negative bacterial infections, sepsis, retrospective study

\section{Introduction}

Nosocomial or health care-associated gram negative infections account for a high morbidity and mortality rate among hospitalized patients [1]. It is estimated that in 2002, a total of 1.7 million hospital-acquired infections occurred (4.5 per 100 admissions) and almost 99,000 deaths resulted from or were associated with a hospital-acquired infection [2], making hospital-acquired infections the sixth leading cause of death in the United States [3]. The situation is even more alarming in developing countries like India. Bacterial Sepsis is a systemic inflammatory response syndrome (SIRS) occurring in presence of suspected or proven infection [4]. It is the second most common cause of death in non- coronary intensive care units (ICU) and the tenth overall cause of death in high income countries $[5,6]$. The incidence of sepsis in the past two decades has annually increased by $9 \%$, to reach 240 per 100000 people in the USA by $2013[7,8]$. Some of the most frequently isolated gram negative bacteria in sepsis are Klebsiella spp., Escherichia coli ( $E$. coli), and Pseudomonas aeruginosa (P. aeruginosa) [9]. Endotoxin (LPS) is a major component of the outer membrane of gram 
negative bacteria and a critical factor in the pathogenesis of gram negative bacterial sepsis [10]. Sepsis is a serious medical condition which require immediate medical attention. The probable etiology is immunological response of human body towards different infections in the lungs, urinary tract, skin, abdomen or other part of the body with or without invasive medical procedures like the insertion of catheter/ stent etc. These infections can introduce bacteria into the bloodstream which ultimately adversely affects all body organs functioning and can result in multi organ complication/ failure and death.

Gram negative pathogens are highly efficient at up-regulating or acquiring genes that code for mechanisms of antibiotic drug resistance, especially in the presence of antibiotic selection pressure [11]. Multi drug-resistant Gram-negative bacteria have emerged as a major threat to hospitalized patients and have been reported to be associated with mortality rates ranging from 30 to $70 \%$ [12-18]. Decade ago, cephalosporins along with other antibiotics were the drug of choice for sepsis management which later shifted to carbapenems due to emergence of resistant stains $[\mathbf{1 9 , 2 0}]$. This is mainly because carbapenems are not inactivated by these enzymes in vitro and have been demonstrated to have adequate effectiveness for the treatment of serious Gram-negative bacterial infections at various body sites till date $[\mathbf{2 0 , 2 1}]$. However in past few years, carbapenem resistance among gram negative bacteria has been reported increasingly throughout the world and India [22-27]. This carbapenem resistance is mainly attributed to the ability of the bacteria to produce MBL enzymes (carbapenamases) and due to efflux of penems by smart bacteria. In India, the prevalence of MBLs range from 8\% to $79 \%$ [28-31].

Use of adjuvants along with beta lactam and beta lactamase inhibitor combinations is a new approach to treat these multi drug resistant bacterial infections [32]. Fixed dose combination of Ceftriaxone+sulbactam+adjuvant disodium edetate is one such novel antibiotic adjuvant entity (AAE) approved by the Drug Controller General of India (DCGI) and increasingly used in Indian hospitals. Thus in view of all growing resistance to standard of care for sepsis management, rising therapy failures, newer therapies were evaluated for their safety and efficacy in sepsis. Present study is a retrospective analysis of the clinical and microbiological efficacy of AAE mono-therapy and AAE plus colistin combination therapy in management of gram negative sepsis.

\section{Materials and methods}

\section{Patients and antibiotic therapy}

Study was conducted at 200 bedded tertiary care hospital. We retrospectively reviewed data of clinically cured patients in whom AAE was used empirically for management of sepsis. Data of 50 patients (Figure 1) suffering from Gram negative bacterial sepsis like abdominal, respiratory and urosepsis, who were treated between March 2013 to December 2014 were evaluated. These patients were administered with a novel antibiotic adjuvant entity AAE, (Ceftriaxone+sulbactam+EDTA)

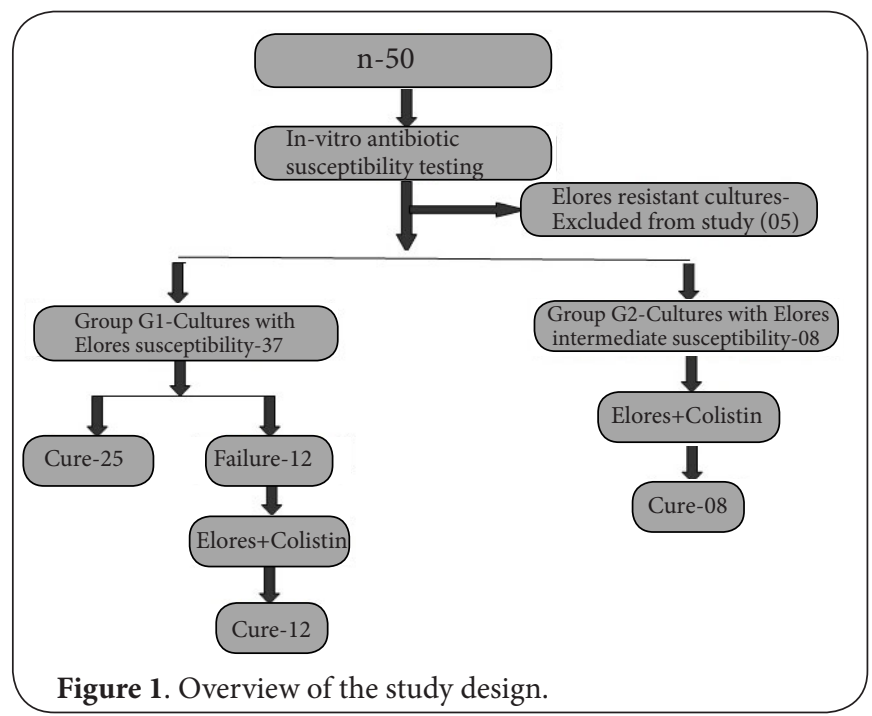

BID empirically, herein after termed as AAE. Among evaluated 50 patients, 45 clinically cured patients, showing sensitivity towards AAE were considered in the study, while the rest 05 (AAE resistant) patients were excluded from the study. Characters like gender, age, infection type, source of infection, causative pathogen, dosage and regime of antibiotic therapy for these patients were recorded. AAE was initially started empirically based on the clinical presentation and treating physician's decision and was continued or shifted based on the in-vitro microbiological susceptibility report and clinical response. A dose of $3.0 \mathrm{~g} / 12$ hours of AAE was used and in cases were patients were more critical or failed to respond to $A A E$ alone, colistin therapy with a loading dose of 9 MIU followed by BD doses of 4.5 MIU were used along with previous antibiotic.

On retrospective evaluation based on microbial susceptibility patients were divided in two groups. Patients showing susceptibility to AAE 37 (82.22\%) were kept in Group G-1, where as the remaining $08(17.77 \%)$ cultures showing intermediate susceptibility were kept in Group G-2. On day 03 of treatment, along with bacteriological evaluations, the progress of the therapy (measured in terms of the improvement in the clinical signs and symptoms) was also recorded. Patients showing improvement in clinical signs and symptoms (like stabilization of vital signs and lab parameters) AAE empiric therapy was continued. Patients which failed to respond to AAE mono-therapy clinically (showing no/less improvement) despite microbial sensitivity, were switched to AAE and colistin combination therapy. Group G2 patients, showing intermediate susceptibility towards AAE were treated with colistin along with the empiric $A A E$ after $3^{\text {rd }}$ day till end of therapy.

\section{In-vitro microbial antibiotic susceptibility testing} Antimicrobial susceptibility testing of the pathogens isolated from the patients was done by Kirby-Bauer disk diffusion method as recommended by the Clinical Laboratory Standards Institute (CLSI) guidelines (2012) [33]. Meropenem disk (10 
$\mu \mathrm{g})$, ertapenem disk $(10 \mu \mathrm{g})$, doripenem disk $(10 \mu \mathrm{g})$, piperacillin+tazobactam disk $(100 / 10 \mu \mathrm{g})$, Amoxycillin+Clavulinic acid $(20 / 10 \mu \mathrm{g})$, cefoperazone+sulbactam $(75 / 30 \mu \mathrm{g})$ and ceftriaxone+sulbcatam+EDTA disk $(45 \mu \mathrm{g})$ were procured from Hi-media (Mumbai, India) and used in the study. Sensitivity of isolated organisms against antibiotics were reported as sensitive (S), Intermediate (I) or resistant (R) based on the breakpoints.

\section{Clinical analysis of patients}

Patient's clinical status was evaluated based on the clinical signs and symptoms associated with Gram negative bacterial sepsis like fever, chills, decreased urination, hypo tension, rapid pulse rate, increased heart beat, nausea, vomiting diarrhoea, difficulty in breathing, deranged laboratory parameters like low hemoglobin, platelet count, increased/decreased total leukocyte count, deranged LFT and RFT depending upon the type of original infection (origin of sepsis: respiratory, abdominal or urosepsis). The signs symptoms and laboratory parameters of base line visit, after 3 days of AAE empirical antibiotic therapy and also the end of therapy were evaluated. BAL, ET secretions, urine or blood samples from the patients were tested for the diagnosis of causative pathogens. Clinical response of the therapy evaluated at the end of the treatment was recorded and classified as cured (complete remission of local and systemic signs and symptoms), improved (improvement of local and systemic signs and symptoms but without complete resolution) or failure (no improvement or deterioration of signs and symptoms).

\section{Results}

\section{Patients and demographic characteristics}

45 clinically cured patients out of 50 patients taken retrospectively, in the considered study period at a tertiary care hospital were diagnosed with infections with AAE sensitive pathogens. The demographic and baseline characteristics of these 45 patients whose data were analysed in this study are given in Table 1. Respiratory sepsis was the most predominant infection diagnosed, contributing a share of $46.66 \%$ (21) among the 45 treated patients. Respiratory sepsis was followed by urosepsis observed in 17 (37.77\%) patients. However abdominal sepsis was in $07(15.55 \%)$ patients which is comparatively low than other two sepsis types (Table 1). Among the 45 single bacterial infections, 29 (64.44\%) infections were caused due to pathogens belonging to Enterobacteriaceae family, with $E$. coli accounting for $58.62 \%$ (17) and Klebsiella sp. for $41.37 \%$ (12) within this family. The remaining 16 (7 Acinetobacter sp.+9 Pseudomonas sp.) isolates were of non-Enterobacteriaceae family which caused infections in $35.55 \%$ patients (Table 1 ).

\section{In-vitro microbial antibiotic susceptibility testing} The results of $I n$-vitro microbial antibiotic susceptibility testing carried out for isolated pathogens against AAE and different antibiotics are depicted in Table 2. Among the 50 patients evaluated, cultures isolated from 45 patients showed sensitivity
Table 1. Demographics characteristics of the patients treated during the study period.

\begin{tabular}{ll}
\hline Characteristic & Value \\
\hline Evaluable patients & 45 \\
Age, mean year SD & $56.88 \pm 13.77$ \\
No. male:female & $29: 21(58 \%: 42 \%)$ \\
\hline Type of infection (\%) & \\
\hline Abdominal sepsis & $07(15.55 \%)$ \\
Respiratory sepsis & $21(46.66 \%)$ \\
Urosepsis & $17(37.77 \%)$ \\
Sepsis due to E coli & $17(37.77 \%)$ \\
Sepsis due to Klebsiella sp. & $12(26.66 \%)$ \\
Sepsis due to Pseudomonas sp. & $09(20.00 \%)$ \\
Sepsis due to Acinetobacter sp. & $07(15.55 \%)$ \\
\hline
\end{tabular}

towards $\mathrm{AAE}$ and the remaining 5 were resistant to it. Among these 45 pathogens, 37 (82.22\%) were susceptible to AAE and $08(17.18 \%)$ showed intermediate susceptibility. Among the isolated pathogens highest susceptibility towards AAE was observed in E coli (88.23\%) and Pseudomonas sp. (85.71\%) closely followed by Acinetobacter sp. (77.77\%) and Klebsiella sp. (75\%). Ertapenem and Meropenem were equally susceptible against $E$ coli with $88.23 \%$ and $77.47 \%$ susceptibility respectively. However, the remaining pathogens showed less susceptible to penems indicating either prevalence of metallo betalactamses or efflux type resistance usually observed in penems. Doripenem, although a newer penem was found to be the least susceptible drug (Table 2). However all the tested pathogens showed low non significant $(<10 \%)$ susceptibilities towards the other tested antibiotics (data not shown).

\section{Efficacy of antibiotic therapy}

All the 45 patients considered for the study were given AAE empirically. Among these, 37 patients of group 1 which were identified with AAE susceptible bacterial infections with signs of clinical improvement, were continued with the same treatment. Successful clinical response was observed in 25/37 patients at the end of mono therapy. The mean treatment duration among these 25 patients cured with AAE therapy was (9.6 days \pm 1.44 (SD)). 12 Patients, which failed to respond to AAE clinically (showing less improvement clinically) after 3 days, were switched to AAE and colistin combination therapy. The mean treatment duration among these 12 patients cured with AAE and colistin combination therapy was ( 11.33 days \pm 2.26 (SD)) (Table 3). All the patients of group 2 (8 patients) whose cultures were showing intermediate susceptibility towards AAE and shifted to AAE plus colistin combination therapy, were cured. The mean treatment duration among these 08 patients cured with AAE and colistin combination therapy was (12.87 days \pm 2.53 (SD)) (Table 4). Overall it was found that $55.55 \%$ cases were cured with AAE monotherapy and $44.55 \%$ cases with AAE and colistin combo therapy. 
Sachin Verma, Research Journal of Infectious Diseases 2015,

http://www.hoajonline.com/journals/pdf/2052-5958-3-3.pdf

doi: $10.7243 / 2052-5958-3-3$

Table 2. In-vitro antibiotic susceptibility testing for isolated bacteria.

\begin{tabular}{|c|c|c|c|c|c|c|c|c|c|c|}
\hline \multirow[t]{3}{*}{ S. No. } & \multirow[t]{3}{*}{ Isolated pathogens } & \multirow{3}{*}{$\begin{array}{l}\text { Number of individual } \\
\text { isolates }\end{array}$} & \multicolumn{8}{|c|}{ Susceptibility/resistance \% } \\
\hline & & & \multicolumn{2}{|c|}{ AAE } & \multicolumn{2}{|c|}{ Meropenem } & \multicolumn{2}{|c|}{ Doripenem } & \multicolumn{2}{|c|}{ Ertapenem } \\
\hline & & & $S$ & I & $S$ & I & S & I & $S$ & I \\
\hline 1 & E coli & 17 & 88.23 & 11.77 & 76.47 & 23.53 & 58.82 & 41.18 & 88.23 & 11.77 \\
\hline 2 & Klebsiella sp. & 12 & 75 & 25 & 41.66 & 58.33 & 50 & 50 & 58.33 & 41.67 \\
\hline 3 & Acinetobacter sp. & 09 & 77.77 & 22.23 & 44.44 & 55.55 & 55.55 & 44.45 & 44.44 & 55.55 \\
\hline 4 & Pseudomonas sp. & 07 & 85.71 & 14.28 & 57.14 & 42.86 & 14.28 & 85.72 & 28.57 & 71.42 \\
\hline
\end{tabular}

S: Susceptibility; I: Intermediate susceptibility

Table 3. Summary of antibiotic therapy for the patients with cultures susceptible to AAE.

\begin{tabular}{|c|c|c|c|c|c|c|c|c|}
\hline S. No & Age & Organism & AAE dose & $\begin{array}{l}\text { Duration } \\
\text { (days) }\end{array}$ & $\begin{array}{l}\text { Clinical } \\
\text { response }\end{array}$ & Therapy shifted to AAE+Colistin & $\begin{array}{l}\text { Duration } \\
\text { (days) }\end{array}$ & $\begin{array}{l}\text { Clinical } \\
\text { response }\end{array}$ \\
\hline 1 & 44 & Pseudomonas sp. & $3.0 \mathrm{~g}$ & 9 & Cured & NA & $\mathrm{NA}$ & NA \\
\hline 2 & 81 & E coli & $3.0 \mathrm{~g}$ & 3 & Failure & $\begin{array}{l}3.0 \mathrm{~g} \text { AAE+colistin } \\
\text { (9 MIU loading and } 4.5 \text { MIU BID) }\end{array}$ & 6 & Cured \\
\hline 3 & 59 & Klebsiella sp. & $3.0 \mathrm{~g}$ & 9 & Cured & NA & NA & NA \\
\hline 4 & 78 & Klebsiella sp. & $3.0 \mathrm{~g}$ & 3 & Failure & $\begin{array}{l}3.0 \mathrm{~g} \text { AAE+colistin } \\
\text { (9 MIU loading and } 4.5 \text { MIU BID) }\end{array}$ & 9 & Cured \\
\hline 5 & 52 & Klebsiella sp. & $3.0 \mathrm{~g}$ & 8 & Cured & NA & NA & NA \\
\hline 6 & 55 & Acinetobacter sp. & $3.0 \mathrm{~g}$ & 11 & Cured & NA & NA & NA \\
\hline 7 & 74 & Acinetobacter sp. & $3.0 \mathrm{~g}$ & 3 & Failure & $\begin{array}{l}3.0 \mathrm{~g} \text { AAE+colistin } \\
\text { ( } 9 \text { MIU loading and } 4.5 \text { MIU BID) }\end{array}$ & 11 & Cured \\
\hline 8 & 71 & E coli & $3.0 \mathrm{~g}$ & 9 & Cured & NA & NA & NA \\
\hline 9 & 69 & Klebsiella sp. & $3.0 \mathrm{~g}$ & 12 & Cured & NA & NA & NA \\
\hline 10 & 39 & E coli & $3.0 \mathrm{~g}$ & 9 & Cured & NA & NA & NA \\
\hline 11 & 45 & Klebsiella sp. & $3.0 \mathrm{~g}$ & 10 & Cured & NA & NA & NA \\
\hline 12 & 61 & Klebsiella sp. & $3.0 \mathrm{~g}$ & 3 & Failure & $\begin{array}{l}3.0 \mathrm{~g} \text { AAE}+ \text { colistin } \\
\text { ( } 9 \text { MIU loading and } 4.5 \text { MIU BID) }\end{array}$ & 7 & Cured \\
\hline 13 & 52 & Klebsiella sp. & $3.0 \mathrm{~g}$ & 8 & Cured & NA & NA & NA \\
\hline 14 & 59 & Pseudomonas sp. & $3.0 \mathrm{~g}$ & 3 & Failure & $\begin{array}{l}\text { 3.0 g AAE+ colistin } \\
\text { ( } 9 \text { MIU loading and } 4.5 \text { MIU BID) }\end{array}$ & 12 & Cured \\
\hline 15 & 62 & Acinetobacter sp. & $3.0 \mathrm{~g}$ & 9 & Cured & NA & NA & NA \\
\hline 16 & 48 & Acinetobacter sp. & $3.0 \mathrm{~g}$ & 11 & Cured & NA & NA & NA \\
\hline 17 & 81 & Klebsiella sp. & $3.0 \mathrm{~g}$ & 3 & Failure & $\begin{array}{l}3.0 \mathrm{~g} \text { AAE+colistin } \\
\text { ( } 9 \text { MIU loading and } 4.5 \text { MIU BID) }\end{array}$ & 10 & Cured \\
\hline 18 & 57 & E coli & $3.0 \mathrm{~g}$ & 9 & Cured & NA & NA & NA \\
\hline 19 & 64 & E coli & $3.0 \mathrm{~g}$ & 3 & Failure & $\begin{array}{l}3.0 \mathrm{~g} \text { AAE}+ \text { colistin } \\
\text { ( } 9 \text { MIU loading and } 4.5 \text { MIU BID) }\end{array}$ & 6 & Cured \\
\hline 20 & 41 & Pseudomonas sp. & $3.0 \mathrm{~g}$ & 12 & Cured & NA & NA & NA \\
\hline 21 & 37 & E coli & $3.0 \mathrm{~g}$ & 10 & Cured & NA & NA & NA \\
\hline 22 & 56 & E coli & $3.0 \mathrm{~g}$ & 9 & Cured & NA & NA & NA \\
\hline 23 & 35 & Pseudomonas sp. & $3.0 \mathrm{~g}$ & 8 & Cured & NA & NA & NA \\
\hline 24 & 44 & E coli & $3.0 \mathrm{~g}$ & 3 & Failure & $\begin{array}{l}\text { 3.0 g AAE+colistin } \\
\text { ( } 9 \text { MIU loading and } 4.5 \text { MIU BID) }\end{array}$ & 5 & Cured \\
\hline 25 & 78 & E coli & $3.0 \mathrm{~g}$ & 8 & Cured & NA & NA & NA \\
\hline 26 & 46 & E coli & $3.0 \mathrm{~g}$ & 13 & Cured & NA & NA & NA \\
\hline 27 & 58 & Pseudomonas sp. & $3.0 \mathrm{~g}$ & 3 & Failure & $\begin{array}{l}3.0 \mathrm{~g} \text { AAE+colistin } \\
\text { ( } 9 \text { MIU loading and } 4.5 \text { MIU BID) }\end{array}$ & 9 & Cured \\
\hline 28 & 58 & E coli & $3.0 \mathrm{~g}$ & 3 & Failure & $\begin{array}{l}\text { 3.0 g AAE+colistin } \\
\text { ( } 9 \text { MIU loading and } 4.5 \text { MIU BID) }\end{array}$ & 9 & Cured \\
\hline 29 & 49 & Acinetobacter sp. & $3.0 \mathrm{~g}$ & 10 & Cured & NA & NA & NA \\
\hline 30 & 63 & E coli & $3.0 \mathrm{~g}$ & 8 & Cured & NA & NA & NA \\
\hline
\end{tabular}


Sachin Verma, Research Journal of Infectious Diseases 2015,

http://www.hoajonline.com/journals/pdf/2052-5958-3-3.pdf

doi: $10.7243 / 2052-5958-3-3$

Continuation of Table 3.

\begin{tabular}{|c|c|c|c|c|c|c|c|c|}
\hline S. No & Age & Organism & AAE dose & $\begin{array}{l}\text { Duration } \\
\text { (days) }\end{array}$ & $\begin{array}{l}\text { Clinical } \\
\text { response }\end{array}$ & Therapy shifted to AAE+Colistin & $\begin{array}{l}\text { Duration } \\
\text { (days) }\end{array}$ & $\begin{array}{l}\text { Clinical } \\
\text { response }\end{array}$ \\
\hline 31 & 70 & Acinetobacter sp. & $3.0 \mathrm{~g}$ & 3 & Failure & $\begin{array}{l}3.0 \mathrm{~g} \text { AAE+colistin } \\
\text { (9 MIU loading and } 4.5 \text { MIU BID) }\end{array}$ & 10 & Cured \\
\hline 32 & 41 & E coli & $3.0 \mathrm{~g}$ & 11 & Cured & NA & NA & NA \\
\hline 33 & 54 & Klebsiella sp. & $3.0 \mathrm{~g}$ & 9 & Cured & NA & NA & NA \\
\hline 34 & 66 & E coli & $3.0 \mathrm{~g}$ & 9 & Cured & NA & NA & NA \\
\hline 35 & 30 & Pseudomonas sp. & $3.0 \mathrm{~g}$ & 3 & Failure & $\begin{array}{l}3.0 \mathrm{~g} \text { AAE+colistin } \\
\text { (9 MIU loading and } 4.5 \text { MIU BID) }\end{array}$ & 6 & Cured \\
\hline 36 & 59 & E coli & $3.0 \mathrm{~g}$ & 11 & Cured & NA & NA & NA \\
\hline 37 & 32 & Pseudomonas sp. & $3.0 \mathrm{~g}$ & 8 & Cured & NA & NA & NA \\
\hline
\end{tabular}

Table 4. Summary of antibiotic therapy for the patients with cultures intermediate susceptible to AAE.

\begin{tabular}{|c|c|c|c|c|c|c|c|}
\hline S. No & Age & Organism & AAE dose & $\begin{array}{l}\text { Duration } \\
\text { (days) }\end{array}$ & Therapy shifted to AAE+Colistin & $\begin{array}{l}\text { Duration } \\
\text { (days) }\end{array}$ & $\begin{array}{l}\text { Clinical } \\
\text { response }\end{array}$ \\
\hline 1 & 49 & Klebsiella sp. & $3.0 \mathrm{~g}$ & 3 & $\begin{array}{l}\text { 3.0 g AAE+colistin } \\
\text { (9 MIU loading and } 4.5 \text { MIU BID) }\end{array}$ & 8 & Cured \\
\hline 2 & 86 & Pseudomonas sp. & $3.0 \mathrm{~g}$ & 3 & $\begin{array}{l}\text { 3.0 g AAE+colistin } \\
\text { ( } 9 \text { MIU loading and } 4.5 \text { MIU BID) }\end{array}$ & 8 & Cured \\
\hline 3 & 77 & Klebsiella sp. & $3.0 \mathrm{~g}$ & 3 & $\begin{array}{l}3.0 \mathrm{~g} \text { AAE+colistin } \\
\text { ( } 9 \text { MIU loading and } 4.5 \text { MIU BID) }\end{array}$ & 13 & Cured \\
\hline 4 & 63 & Klebsiella sp. & $3.0 \mathrm{~g}$ & 3 & $\begin{array}{l}\text { 3.0 g AAE+colistin } \\
\text { ( } 9 \text { MIU loading and } 4.5 \text { MIU BID) }\end{array}$ & 6 & Cured \\
\hline 5 & 58 & Pseudomonas sp. & $3.0 \mathrm{~g}$ & 3 & $\begin{array}{l}3.0 \mathrm{~g} \text { AAE+colistin } \\
\text { ( } 9 \text { MIU loading and } 4.5 \text { MIU BID) }\end{array}$ & 9 & Cured \\
\hline 6 & 55 & E coli & $3.0 \mathrm{~g}$ & 3 & $\begin{array}{l}3.0 \mathrm{~g} \text { AAE+colistin } \\
\text { ( } 9 \text { MIU loading and } 4.5 \mathrm{MIU} \text { BID) }\end{array}$ & 11 & Cured \\
\hline 7 & 49 & Acinetobacter sp. & $3.0 \mathrm{~g}$ & 3 & $\begin{array}{l}3.0 \mathrm{~g} \text { AAE+colistin } \\
\text { ( } 9 \text { MIU loading and } 4.5 \text { MIU BID) }\end{array}$ & 13 & Cured \\
\hline 8 & 55 & E coli & $3.0 \mathrm{~g}$ & 3 & $\begin{array}{l}3.0 \mathrm{~g} \text { AAE+colistin } \\
\text { ( } 9 \text { MIU loading and } 4.5 \text { MIU BID) }\end{array}$ & 11 & Cured \\
\hline
\end{tabular}

\section{Discussion}

Gram negative bacteria have often been implicated in the pathogenesis of sepsis and septic shock [34]. Sepsis is the number one cause of deaths in the intensive care unit accounting for some 200,000 fatalities in the US annually. Sepsis incidences continues to rise in US [35] and worldwide [36], perhaps due to increased invasive procedures, immunosuppression, and drug resistance. Mortality associated with sepsis, unfortunately, has essentially remained unchanged at about 45\% [37], despite tremendous strides in antimicrobial chemotherapy, pointing to the absence of therapeutic strategies aimed specifically at the pathophysiology of sepsis. The current data represents the retrospective study of 45 gram negative sepsis patients who were treated with novel AAE either as mono or combination therapy right from the diagnosis.

In-vitro microbial antibiotic susceptibility testing of the bacteria isolated from the 45 patients yielded 2 group of bacteria; G1-the bacteria which are susceptible to AAE and G2-the bacteria showing intermediate susceptibility towards AAE. Out of 37 patients, 25 (67.56\%) patients of group G1, which were treated with AAE achieved clinical success. These results advocate the consistency of in vitro and in vivo results. A higher percentage of the clinical cure rates justifies the selection of AAE for the empirical therapy, because delayed appropriate antibiotic therapy is known to be strongly associated with increased mortality in patients with septic shock [38]. Thus the appropriate empirical therapy is required to reduce the mortality rates in sepsis infections. In 12 (32.43\%) patients, who failed respond to the AAE empirical therapy, clinical success was achieved when colistin was given along with AAE as a combination therapy. Similar results with complete clinical success was achieved, in the patients with AAE intermediate susceptible bacterial infection, when AAE and colistin combination therapy was used. The efficiency of $A A E$ and colistin combination therapy might be because of the synergy between the two drugs. The mechanisms of synergy are often not fully understood, however it is believed that, colistin, increases the permeability of other antibiotic through the bacterial outer membrane by a detergent mechanism [39]. This mechanism can counteract acquired resistance mediated by decreased antibiotic permeability (e.g., porin loss), and will also enable antibiotics which fail to act in case of severe 
bacterial infections like sepsis [40]. The clinical success results obtained with the AAE and colistin combination therapy are justifiable by the support of the previous reports. Combination therapy for suspected sepsis and severe gram-negative infections typically includes a broad-spectrum beta-lactam and colistin [41-45].

\section{Conclusion}

The present retrospective study generated a representative status of the susceptibility among gram negative pathogens isolated from sepsis infections and its effective management using cabapenem sparing therapy of novel AAE with or without colistin. The major aspects emerged from the present study are, the rise of the carbapenem resistance incidences among the pathogens isolated from sepsis, proved efficacy of new AAE (both in mono as well as in combination with colistin) to treat the infections caused by gram negative bacteria. The present study advocates the high efficacy of beta lactam and beta lactamase inhibitor combinations with an adjuvant in both mono and combination therapies.

\section{Competing interests}

The author declares that he has no competing interests.

Publication history

EIC: Ishtiaq Qadri, King Abdul Aziz University, Saudi Arabia.

Received: 20-Jun-2015 Final Revised: 21-Jul-2015

Accepted: 12-Aug-2015 Published: 19-Aug-2015

\section{References}

1. Boucher HW, Talbot GH, Bradley JS, Edwards JE, Gilbert D, Rice LB, Scheld $M$, Spellberg $B$ and Bartlett J. Bad bugs, no drugs: no ESKAPE! An update from the Infectious Diseases Society of America. Clin Infect Dis. 2009; 48:1-12. | Article | PubMed

2. Klevens RM, Edwards JR, Richards CL, Jr., Horan TC, Gaynes RP, Pollock DA and Cardo DM. Estimating health care-associated infections and deaths in U.S. hospitals, 2002. Public Health Rep. 2007; 122:160-6. | PubMed Abstract | PubMed Full Text

3. Kung HC, Hoyert DL, Xu J and Murphy SL. Deaths: final data for 2005. Natl Vital Stat Rep. 2008; 56:1-120. | Pdf | PubMed

4. LaRosa SP and Opal SM. Sepsis strategies in development. Clin Chest Med. 2008; 29:735-47. | Article | PubMed

5. Visintin A, Halmen KA, Latz E, Monks BG and Golenbock DT. Pharmacological inhibition of endotoxin responses is achieved by targeting the TLR4 coreceptor, MD-2. J Immunol. 2005; 175:6465-72. | Article | PubMed

6. Kim HM, Park BS, Kim JI, Kim SE, Lee J, Oh SC, Enkhbayar P, Matsushima $\mathrm{N}$, Lee $\mathrm{H}$, Yoo OJ and Lee JO. Crystal structure of the TLR4-MD-2 complex with bound endotoxin antagonist Eritoran. Cell. 2007; 130:906-17. | Article | PubMed

7. Solomon SB, Cui X, Gerstenberger E, Danner RL, Fitz Y, Banks SM, Natanson C and Eichacker PQ. Effective dosing of lipid A analogue E5564 in rats depends on the timing of treatment and the route of Escherichia coli infection. J Infect Dis. 2006; 193:634-44. | Article | PubMed

8. Angus DC, Linde-Zwirble WT, Lidicker J, Clermont G, Carcillo J and Pinsky MR. Epidemiology of severe sepsis in the United States: analysis of incidence, outcome, and associated costs of care. Crit Care Med. 2001; 29:1303-10. | PubMed

9. Opal SM, Garber GE, LaRosa SP, Maki DG, Freebairn RC, Kinasewitz GT,
Dhainaut JF, Yan SB, Williams MD, Graham DE, Nelson DR, Levy H and Bernard GR. Systemic host responses in severe sepsis analyzed by causative microorganism and treatment effects of drotrecogin alfa (activated). Clin Infect Dis. 2003; 37:50-8. | Article | PubMed

10. Beutler $B$ and Rietschel ET. Innate immune sensing and its roots: the story of endotoxin. Nat Rev Immunol. 2003; 3:169-76. | Article | PubMed

11. Peleg AY and Hooper DC. Hospital-Acquired Infections Due to GramNegative Bacteria. N Engl J Med. 2010; 362:1804-13. | Article

12. Bratu S, Landman D, Haag R, Recco R, Eramo A, Alam M and Quale J. Rapid spread of carbapenem-resistant Klebsiella pneumoniae in New York City: a new threat to our antibiotic armamentarium. Arch Intern Med. 2005; 165:1430-5. | Article | PubMed

13. Bryan CS, Reynolds KL and Brenner ER. Analysis of 1,186 episodes of gram-negative bacteremia in non-university hospitals: the effects of antimicrobial therapy. Rev Infect Dis. 1983; 5:629-38. | Article | PubMed

14. Geerdes HF, Ziegler D, Lode H, Hund M, Loehr A, Fangmann W and Wagner J. Septicemia in $\mathbf{9 8 0}$ patients at a university hospital in Berlin: prospective studies during 4 selected years between 1979 and 1989. Clin Infect Dis. 1992; 15:991-1002. | Article | PubMed

15. Gudiol C, Tubau F, Calatayud L, Garcia-Vidal C, Cisnal M, Sanchez-Ortega I, Duarte R, Calvo M and Carratala J. Bacteraemia due to multidrugresistant Gram-negative bacilli in cancer patients: risk factors, antibiotic therapy and outcomes. J Antimicrob Chemother. 2011; 66:657-63. | Article | PubMed

16. Leibovici L, Samra Z, Konigsberger H, Drucker M, Ashkenazi S and Pitlik SD. Long-term survival following bacteremia or fungemia. JAMA. 1995; 274:807-12. | Article | PubMed

17. Mouloudi E, Protonotariou E, Zagorianou A, losifidis E, Karapanagiotou A, Giasnetsova T, Tsioka A, Roilides E, Sofianou D and Gritsi-Gerogianni $\mathrm{N}$. Bloodstream infections caused by metallo-beta-lactamase/Klebsiella pneumoniae carbapenemase-producing K. pneumoniae among intensive care unit patients in Greece: risk factors for infection and impact of type of resistance on outcomes. Infect Control Hosp Epidemiol. 2010; 31:1250-6. | Article | PubMed

18. Perl TM, Dvorak L, Hwang T and Wenzel RP. Long-term survival and function after suspected gram-negative sepsis. JAMA. 1995; 274:338-45. | Article | PubMed

19. Paterson DL. Recommendation for treatment of severe infections caused by Enterobacteriaceae producing extended-spectrum betalactamases (ESBLs). Clin Microbiol Infect. 2000; 6:460-3. | Article | PubMed

20. Perrott J, Mabasa VH and Ensom MH. Comparing outcomes of meropenem administration strategies based on pharmacokinetic and pharmacodynamic principles: a qualitative systematic review. Ann Pharmacother. 2010; 44:557-64. | Article | PubMed

21. Falagas ME and Karageorgopoulos DE. Extended-spectrum betalactamase-producing organisms. J Hosp Infect. 2009; 73:345-54. | $\underline{\text { Article }}$ I PubMed

22. Francis RO, Wu F, Della-Latta P, Shi J and Whittier S. Rapid detection of Klebsiella pneumoniae carbapenemase genes in enterobacteriaceae directly from blood culture bottles by real-time PCR. Am J Clin Pathol. 2012; 137:627-32. | Article | PubMed

23. Hu F, Chen S, Xu X, Guo Y, Liu Y, Zhu D and Zhang Y. Emergence of carbapenem-resistant clinical Enterobacteriaceae isolates from a teaching hospital in Shanghai, China. J Med Microbiol. 2012; 61:132-6. | Article | PubMed

24. Gupta E, Mohanty S, Sood S, Dhawan B, Das BK and Kapil A. Emerging resistance to carbapenems in a tertiary care hospital in north India. Indian J Med Res. 2006; 124:95-8. | Pdf | PubMed

25. Grundmann H, Livermore DM, Giske CG, Canton R, Rossolini GM, Campos J, Vatopoulos A, Gniadkowski M, Toth A, Pfeifer Y, Jarlier V and Carmeli Y. Carbapenem-non-susceptible Enterobacteriaceae in Europe: conclusions from a meeting of national experts. Euro Surveill. 2010; 15:46. | Article | PubMed

26. Varaiya A, Kulkarni M, Bhalekar P and Dogra J. Incidence of metallo-beta- 
lactamase-producing Pseudomonas aeruginosa in diabetes and cancer patients. Indian J Pathol Microbiol. 2008; 51:200-3. | Article | PubMed

27. Chaudhary $M$ and Payasi $A$. Antimicrobial susceptibility patterns and molecular characterization of Klebsiella pneumoniae clinical isolates from north Indian patients. Int J Med Med Sci. 2013; 46:1218-24. I Pdf

28. Deshpande P, Rodrigues C, Shetty A, Kapadia F, Hedge A and Soman R. New Delhi Metallo-beta lactamase (NDM-1) in Enterobacteriaceae: treatment options with carbapenems compromised. J Assoc Physicians India. 2010; 58:147-9. | PubMed

29. Chakraborty D, Basu S and Das S. A study on infections caused by metallo-betalactamase producing gram-negative bacteria in intensive care unit patients. Amer J Infect Dis. 2010; 6:34-9. | Pdf

30. Datta S, Wattal C, Goel N, Oberoi JK, Raveendran R and Prasad KJ. A ten year analysis of multi-drug resistant blood stream infections caused by Escherichia coli \& Klebsiella pneumoniae in a tertiary care hospital. Indian J Med Res. 2012; 135:907-12. | Article | PubMed Abstract | PubMed Full Text

31. Hodiwala A, Dhoke R and Urhekar AD. Incidence of metallo-betalactamase producing Pseudomonas, Acinetobacter \& Enterobacterial isolates in hospitalised patients. Int J Pharm Biol Sci. 2013; 3:79-83. I Pdf

32. Sahu M, Sanjith S, Bhalekar P and Keny D. Waging war against extended spectrum Beta lactamase and metallobetalactamase producing pathogens- novel adjuvant antimicrobial agent cse1034- an extended hope. J Clin Diagn Res. 2014; 8:DC20-3. | Article | PubMed Abstract | PubMed Full Text

33. Clinical Laboratory Standard Institute. Performance Standards for Antimicrobial Susceptibility Testing; Twenty-Second Informational Supplement. Clinical Laboratory Standard Institute. Wayne, Pennsylvania, USA. 2012; 31

34. Abe R, Oda S, Sadahiro T, Nakamura M, Hirayama Y, Tateishi Y, Shinozaki K and Hirasawa H. Gram-negative bacteremia induces greater magnitude of inflammatory response than Gram-positive bacteremia. Crit Care. 2010; 14:R27. | Article | PubMed Abstract | PubMed Full Text

35. Martin GS, Mannino DM, Eaton S and Moss M. The epidemiology of sepsis in the United States from 1979 through 2000. N Engl J Med. 2003; 348:1546-54. | Article | PubMed

36. Moss M and Martin GS. A global perspective on the epidemiology of sepsis. Intensive Care Med. 2004; 30:527-9. I Article I PubMed

37. Cross $A$ and Opal SM. Therapeutic intervention in sepsis with antibody to endotoxin: is there a future? J Endotoxin Res. 1994; 1:57-9. | Article

38. Kumar A, Roberts D, Wood KE, Light B, Parrillo JE, Sharma S, Suppes R, Feinstein D, Zanotti S, Taiberg L, Gurka D and Cheang M. Duration of hypotension before initiation of effective antimicrobial therapy is the critical determinant of survival in human septic shock. Crit Care Med. 2006; 34:1589-96. | PubMed

39. Rahal JJ. Antimicrobial resistance among and therapeutic options against gram-negative pathogens. Clin Infect Dis. 2009; 49 Suppl 1:S4S10. | Article | PubMed

40. Tangden T. Combination antibiotic therapy for multidrug-resistant Gram-negative bacteria. Ups J Med Sci. 2014; 119:149-53. | Article | PubMed Abstract | PubMed Full Text

41. Safdar N, Handelsman J and Maki DG. Does combination antimicrobial therapy reduce mortality in Gram-negative bacteraemia? A metaanalysis. Lancet Infect Dis. 2004; 4:519-27. | Article | PubMed

42. Kumar A, Safdar N, Kethireddy S and Chateau D. A survival benefit of combination antibiotic therapy for serious infections associated with sepsis and septic shock is contingent only on the risk of death: a metaanalytic/meta-regression study. Crit Care Med. 2010; 38:1651-64. Article | PubMed Abstract | PubMed Full Text

43. Tamma PD, Cosgrove SE and Maragakis LL. Combination therapy for treatment of infections with gram-negative bacteria. Clin Microbiol Rev. 2012; 25:450-70. | Article | PubMed Abstract | PubMed Full Text

44. Micek ST, Welch EC, Khan J, Pervez M, Doherty JA, Reichley RM and Kollef $\mathrm{MH}$. Empiric combination antibiotic therapy is associated with improved outcome against sepsis due to Gram-negative bacteria: a retrospective analysis. Antimicrob Agents Chemother. 2010; 54:1742-8. Article | PubMed Abstract | PubMed Full Text
45. Dellinger RP, Levy MM, Rhodes A, Annane D, Gerlach H, Opal SM, Sevransky JE, Sprung CL, Douglas IS and Jaeschke R et al. Surviving sepsis campaign: international guidelines for management of severe sepsis and septic shock: 2012. Crit Care Med. 2013; 41:580-637. | Article | PubMed

\section{Citation:}

Verma S. A retrospective study to evaluate the efficacy of a new antibiotic adjuvant entity $(\beta$-lactam/ $\beta$-lactamase inhibitor/adjuvant disodium edetate combination) for management of sepsis. Res J Infect Dis. 2015; 3:3.

http://dx.doi.org/10.7243/2052-5958-3-3 